\title{
Conclusion
}

We report of a young and healthy patient with capillary leak syndrome. Antiinterleukin 2 receptor was negative, however it was tested while the patient was improving and only $50 \%$ of patients are positive at the time of diagnosis. Our main efforts should focus on prevention of recurrent attacks.

\section{SINDROMUL DE EXTRAVAZARE CAPILARĂ ASOCIAT CU INSUFICIENȚĂ RESPIRATORIE ACUTĂ ŞI RABDOMIOLIZĂ}

\section{Rezumat:}

Sindromul de extravazare capilară este un sindrom rar, idiopatic, caracterizat prin atacuri recurente de creștere a permeabilității capilare, având ca rezultat o ieșire a proteinelor plasmatice prin peretele capilar, ducând la șoc hipovolemic, hemoconcentrație și rabdomioliză. Tratamentul este suportiv în timpul accesului și de prevenție cu salbutamol, plasmafereză și corticosteroizi.

Cuvinte cheie: sindrom de extravazare capilară, rabdomioliză, insuficiență respiratorie acută.

\section{Introducere:}

Sindromul sistemic idiopatic de extravazare capilară (boala Clarkson) este un sindrom clinic rar, descris prima dată în 1960, caracterizat prin episoade acute de edem generalizat, șoc hipovolemic sever datorat creșterii permeabilității capilare și pierderii de proteine plasmatice prin peretele capilar în interstițiu [1]. Episoadele pot fi severe dacă nu sunt recunoscute şi tratate la timp. Descriem cazul unei paciente tinere, cu sindrom sistemic de extravazare capilară combinat cu insuficiență respiratorie acută, necesitând ventilaţie mecanică, cu rabdomioliză şi sindrom de compartiment.

\section{Prezentarea cazului:}

Pacienta în vârstă de 24 ani se prezintă la serviciul de urgență pentru cefalee, dureri ale extremităților, febră, grețuri și vărsături, simptome care au debutat cu trei zile anterior. Se plânge și de senzație de umflare, dar fără erupții sau dificultăți în respirație. Neagă utilizarea medicamentelor sau altor substanțe, cu excepția paracetamolului ocazional. Antecedentele patologice nu sunt semnificative, cu excepția unui avort în urmă cu patru luni.

La examenul obiectiv este alertă, cu semne vitale: tensiune arterială normală $110 / 70 \mathrm{mmHg}$, tahicardie sinusală 145/min și fără febră. Fața este edematoasă, fără semne de edem al corzilor vocale și fără congestie venoasă jugulară. În rest, examinarea a arătat relaţii normale, inclusiv examinarea neurologică. Testele sangvine: VSH 5, hematocrit 50 (42-52), CPK 1300U/L (24-195U/L), LDH 650U/L (230-460U/L). Electroliții și funcția renală au fost normale. Analizele de urină: proteinurie, leucociturie, osmolaritate 800 , cu sodiu urinar $5 \mathrm{meq} / \mathrm{L}$, mioglobina urinară negativă. Testele pentru toxice au fost negative pentru barbiturice, benzodiazepine, amfetamine, cocaină, fenciclidine și antidepresive triciclice. Examinarea ginecologică a arătat relații normale, iar $\beta$ HCG a fost negativă. Pacienta a fost internată la departamentul de medicină internă, fiind inițiată hidratarea cu soluție salină, bicarbonat şi diureză forțată. În a treia zi, pacienta a prezentat dificultăți în respirație şi devine oligurică. Radiografia toracică evidențiază congestie pulmonară, iar ecocardiografia arată un epanşament mic spre moderat pericardic, cu o disfuncție ventriculară stângă la limită. Mai târziu în aceeaşi zi, condiția pacientei se deteriorează, tensiunea arterială scade la $90 / 60$ mmHg, cu dispnee şi insuficiență respiratorie acută, necesitând ventilație mecanică, noradrenalină şi dobutamină pentru a o stabiliza hemodinamic. Testele sangvine arată albumina $1,5 \mathrm{~g} / \mathrm{dl}(3,2-4,6 \mathrm{~g} / \mathrm{dl})$, care până în urmă cu două zile era normală, CPK de 16,000U/L, osmolaritatea urinei de 1100 şi sodiu urinar $3 \mathrm{mEq} / \mathrm{L}$; gazele sangvine arată acidoză metabolică. Testele pentru funcția renală au fost normale pe tot parcursul internării. 
A fost suspicionat un sindrom de extravazare capilară, fiind recoltate nivelurile de antiinterleukină 2, şi a fost tratată cu soluții coloidale şi cristaloide, precum şi cu furosemid, antibiotice şi corticosteroizi. Nivelurile antiinterleukinei 2 au fost normale. Două zile mai târziu, condiția clinică s-a îmbunătățit semnificativ: tensiunea s-a stabilizat, oliguria s-a remis, analizele de laborator s-au ameliorat progresiv, iar după opt zile pacienta a fost externată cu o stare generală bună.

\section{Discuții}

Sindromul sistemic de extravazare capilară este caracterizat de episoade acute de edem generalizat, șoc hipovolemic sever prin creșterea permeabilității capilare și pierderea proteinelor plasmatice prin peretele capilar în interstițiu. În faza a doua are loc o reintrare masivă a lichidelor în circulație, cu edem pulmonar [1].

Tabloul clinic variază de la creştere cronică sau episodică a greutății, până la episoade dramatice hipotensive cu şoc, dureri abdominale, vărsături şi leziuni cutanate constând din erupție maculară fotosensibilă şi scleroasă [2-5]. O manifestare rară a acestui sindrom este rabdomioliza datorată creșterii presiunii compartimentale, cu mionecroză ischemică și insuficiență renală [6].

Modificările de laborator includ hipoalbuminemia și hemoconcentrația extremă.

O modificare comună este gammopatia monoclonală. Apariția unui mielom multiplu este rară, un caz de sindrom de extravazare capilară a fost descris ca precedând o leucemie cu celule plasmocitare [4].

Mecanismul patogenetic care stă la baza creșterii temporare a permebilității patului capilar al musculaturii scheletale este necunoscut, deși au fost sugerate câteva mecanisme, inclusiv rolul citokinelor, cunoscut fiind faptul că IL-2 cauzează leziuni endoteliale și hiperpermeabilitate capilară. Cicardi și colab. [2] au demonstrat apariția receptorilor celulari pentru IL-2 în timpul crizelor și prezența infiltratelor limfocitare CD-8 pozitive perivasculare, care înconjoară celulele endoteliale lezate, la pacienții cu sindrom de extravazare capilară. A fost sugerat de asemenea și posibilul rol al metaboliților de 5 lipooxigenază, al acidului 5 hidroxieicosatetraenoic și al IL-B4, în apariția hiperpermeabilității capilare [4].

Tratamentul este de obicei empiric, constând în administrarea de perfuzii de volum și forțarea diurezei alcaline în rabdomioliză. Trebuie subliniat faptul că refacerea volumului circulant poate agrava leziunea musculară $[4,5]$.

Terapia preventivă este esențială, administrându-se corticosteroizi, antihistaminice, antiinflamatorii, danazol și antifibrinolitice.

Deoarece majoritatea pacienților au paraproteine monoclonale, este utilizată și plasmafereza, în combinație cu anti CD-20-Rituximab, al cărei efect poate duce la eliminarea imunoglobulinelor patogenetice și complexelor imune, sau inhibiția leucotrienelor [5, 6]. Tratamentul experimental cu anti IL-2, aminofilină şi terbutalină, cunoscut că blochează efectul IL-2, inhibă extravazarea macromoleculelor ca răspuns la variați stimuli ca bradikinina şi histamina. Tratamentul cu prednison și terbutalină scade frecvența episoadelor la unii pacienți. Alții sugerează tratamentul profilactic cu thalidomidă ca și imunomodulator al inhibării producției de alfa-TNF, precum și cu inhibitori de C1 esterază [5].

\section{Concluzii}

Am prezentat cazul unei paciente tinere aparent sănătoase, cu un sindrom de extravazare capilară. Receptorii pentru antiinterleukină 2 au fost negativi, deși această testare a fost făcută doar când pacienta prezenta o ameliorare semnificativă, iar dintre pacienți doar $50 \%$ sunt pozitivi la momentul diagnosticului. Eforturile terapeutice principale ale noastre au fost concentrate asupra prevenirii recurenței crizelor. 


\section{References (Referințe):}

1. Clarkson B, Thompson D, Horwith M, Luckey EH. Cyclical edema and shock due to increased capillary permeability. Am. J. Med 1960;29:193-216

2. Cicardi M, Gardinali M, Bisiani G, Rosti A, Allavena P, Agostoni A. The systemic capillary syndrome: appearance of interleukin-2-receptor-positive cells during attacks. Ann Intern Med. 1990;113 (6):475-7.

3. Atkinson JP, Waldmann TA, Stein SF, et al. Systemic capillary leak syndrome and monoclonal IgG gammopathy. Medicine 1997;56(3):225-239

4. Airaghi L, Montori D, Santambrogio L, Miadonna A, Tedeschi A. Chronic systemic capillary leak syndrome. Report of a case and review of the literature. J Intern Med. 2000;247(6):731-5.

5. Amoura Z, Papo T, Ninet J, Hatron PY, Guillaumie J, Piette AM, Blétry O, Dequiedt P, Talasczka A, Rondeau E, Dutel JL, Wechsler B, Piette JC. Systemic capillary leak syndrome: report on 13 patients with special focus on course and treatment. Am J Med. 1997;103(6):514-9.

6. Vigneau C, Hayman JP, Khoury N, Srear JD, Rondeau E. An unusual evolution of the systemic capillary leak syndrome. Nephrol Dial Transplant. 2002:17(3):492-4

\section{Translation (Traducere): dr Bumbuluț Călin}

